\title{
STRATEGI KOMUNIKASI POLITIK PKS PADA PEMILIHAN UMUM (PEMILU) TAHUN 2019 DI KOTA PEKANBARU
}

\author{
Lailatul Faiza \\ IImu Pemerintahan FISIPOL Universitas Abdurrab \\ lailatulfaiza05@gmail.com
}

\begin{abstract}
Abstrak
Pemilu adalah cara untuk memilih wakil rakyat, keberadaan pemilu menjadi mekanisme politik untuk melakukan rekrutmen dan seleksi orang-orang yang akan duduk di lembaga perwakilan. Pemilu merupakan salah satu ciri dari sistem politik demokrasi. Pemilu tidak terlepas kaitannya dengan suatu partai dan tokoh politik, salah satunya Partai Keadilan Sejahtera (PKS). PKS sebelumnya bernama Partai Keadilan (PK), PKS didirikan di Jakarta pada 20 April 2002. Masing-masing partai dan tokoh politik bersaing untuk mendapatkan perolehan suara terbanyak agar berhasil duduk di kursi parlemen untuk menjadi wakil rakyat, khususnya duduk di kursi legislatif DPRD Kota Pekanbaru. Tujuan penelitian ini adalah untuk mengetahui dan menjelaskan strategi komunikasi Partai Keadilan Sejahtera (PKS) dalam meningkatkan perolehan suara pada pemilihan umum (Pemilu) tahun 2019 di Kota Pekanbaru. Teknik pengumpulan data dalam penelitian ini adalah teknik wawancara dan dokumentasi. Analisa data bersifat deskriptif kualitatif, yaitu mereduksi data, memilih hal-hal pokok, kemudian dilakukan penyajian data dalam bentuk uraian singkat, bagan, hubungan antar kategori dan kemudian diambil kesimpulan dan saran. Berdasarkan hasil penelitian dan pembahasan maka strategi komunikasi politik Partai Keadilan Sejahtera (PKS) dalam meningkatkan perolehan suara pada pemilihan umum (Pemilu) tahun 2019 di Kota Pekanbaru yaitu ketokohan dan kelembagaan, menciptakan kebersamaan, dan membangun konsensus.
\end{abstract}

Kata kunci: pemilu, PKS, strategi komunikasi politik, Pekanbaru

\begin{abstract}
Election is a way to elect representatives of the people. Election is important as a political mechanism for recruitment and selection of people who will be members of parliament. Election is one of the characteristics of a democratic political system. Election cannot be separated in relation to a party and political figures, one of them is the Prosperous Justice Party (PKS). PKS was previously called the Justice Party (PK), PKS was established in Jakarta on April 20, 2002. Each party and political figure competed to get the most votes in order to represent the people in parliament, especially in the legislative council in Pekanbaru City. The purpose of this study is to find out and explain the communication strategy of PKS in increasing votes in the 2019 general election in Pekanbaru City. Data collection techniques in this study are interview and documentation. Data analysis used in this study are descriptive qualitative, namely reducing data, selecting the main things, then presenting data in the form of brief descriptions, charts, relationships between categories and then conclusions and suggestions are taken. Based on the results of research, political communication strategy of PKS in increasing votes in the 2019 general election in Pekanbaru, namely strengthening figures and institutions, creating togetherness, and building consensus.
\end{abstract}

Keywords: election, PKS, political communication strategy, Pekanbaru 


\section{PENDAHULUAN}

Hakikat demokrasi adalah sebuah proses bernegara yang bertumpu kepada rakyat sebagai pemegang tertinggi kedaulatan. Dengan kata lain, pemerintahan demokrasi adalah pemerintahan yang meliputi tiga hal mendasar: pemerintahan dari rakyat, oleh rakyat, untuk rakyat. Telaah tentang peran negara dan masyarakat tidak dapat dilepaskan dari telaah tentang demokrasi. Menurut David Betham dan Kevin Boyle dalam Mufti (2013), demokrasi merupakan bagian dari khazanah dalam membuat keputusan secara kolektif. Demokrasi berusaha untuk mewujudkan keinginan bahwa keputusan yang mempengaruhi masyarakat secara keseluruhan harus diambil oleh semua anggota dan masing-masing anggota mempunyai hak yang sama dalam proses pengambilan/pembuatan keputusan.

Salah satu karakteristik negara yang menganut sistem politik demokrasi ialah terlaksananya pemilihan umum (Pemilu). Pemilu merupakan salah satu ciri dari sistem politik demokrasi. Menurut UU No.7 Tahun 2017 Bab II Pasal 2 ayat 1 tentang pemilu, pemilu dilaksanakan berdasarkan asas langsung, umum, bebas, rahasia, jujur dan adil. Dalam penyelenggaraan pemilu harus melaksanakan pemilu berdasarkan asas-asas sebagaimana yang dimaksud penyelenggaraannya harus memenuhi prinsip mandiri, jujur adil, berkepastian hukum, tertib, terbuka, proporsional, professional, akuntabel, efektif dan efisien. Pemilu dianggap sebagai lambang, sekaligus tolok ukur dari demokrasi, hasil pemilu yang diselenggarakan dalam suasana keterbukaan dengan kebebasan berpendapat kebebasan berserikat. Pemilu merupakan cara memilih wakil rakyat di Negara yang menganut demokrasi sebagai system politik.

Berbicara mengenai pemilu tidak terlepas kaitannya dengan partai. Partai Keadilan Sejahtera (PKS) merupakan sebuah partai yang ikut serta dalam pentas perpolitikan di Indonesia. PKS sebelumnya bernama Partai Keadilan (PK) adalah sebuah partai politik yang berbasis Islam di Indonesia. PKS didirikan di Jakarta pada 20 April 2002. PKS mulai berpartisipasi dalam pemilu sejak 1999, dengan perolehan suara secara tingkat nasional 1.436 .565 atau $1.36 \%$. Pemilu tahun 2004 PKS memperoleh suara sebanyak 8.325.020 atau 7.34\%. Pada pemilu 2009 PKS memperoleh suara sebanyak 8.204.946 atau 7.38\%, dan pada pemilu tahun 2014 PKS memperoleh suara 
sebanyak 8.480 .946 atau $6.79 \%$. Salah satu faktor yang mempengaruhi perolehan suara adalah strategi komunikasi politik. Dalam sebuah partai politik, strategi komunikasi politik adalah salah satu teknik untuk mendapatkan kemenangan dan tercapainya suatu tujuan.

Secara umum bisa dipastikan tidak ada manusia yang lepas dari siklus komunikasi, semua dapat memerankan diri sebagai komunikator. Gabriel Almond mengemukan bahwa komunikasi politik adalah salah satu fungsi yang selalu ada dalam setiap sistem politik (Nimmo 2004). Menurut Galnoor "tanpa komunikasi tidak akan ada usaha bersama, dan demikian tidak akan ada politik" (Cangara 2016). Sedangkan menurut Alfian, komunikasi politik merupakan aliran darah yang mengalir dalam tubuh sistem politik, dan menyebabkan sistem politik itu hidup dan berfungsi (Subiakto dkk, 2012). PKS memiliki Dewan Pimpinan Daerah (DPD) di Pekanbaru yang menjadi bagian dari kesatuan organisasi PKS sebagai partai nasional di Kota Pekanbaru, pada pemilu legislatif tahun 2004 PKS mendapatkan 5 kursi . Pada pemilu berikutnya tahun 2009 PKS meraih 5 kursi di DPRD Kota Pekanbaru. Dengan demikian PKS memiliki posisi yang cukup gemilang dalam kiprah perpolitikan. Akan tetapi pemilu tahun 2014 perolehan suara PKS menurun, PKS meraih 3 kursi. Oleh karena itu, PKS perlu mempersiapkan dan menyusun strategi komunikasi politik untuk menghadapi pemilu 2019 di Kota Pekanbaru untuk meningkatkan perolehan suara. Penelitian ini bertujuan untuk mengetahui dan menjelaskan strategi komunikasi politik Partai Keadilan Sejahtera (PKS) dalam meningkatkan perolehan suara pada pemilihan umum tahun 2019 di Kota Pekanbaru.

\section{STRATEGI KOMUNIKASI POLITIK DAN PARTAI POLITIK}

Menurut Hunger strategi adalah rumusan perencanaan komperhensif tentang bagaimana organisasi mencapai misi dan tujuannya (Tabroni 2014). Sedangkan menurut Michael Allison dan Jude Kaye strategi adalah proses sistematik yang disepakati organisasi dan membangun keterlibatan diantara stakeholder utama tentang prioritas yang hakiki bagi misinya dan tanggap terhadap lingkungan operasi (Tabroni 
2014). Mintzberg dan Quin mengemukakan ada beberapa hal yang berkaitan dengan strategi: strategi sebagai sebuah rencana maksudnya adalah bagaimana suatu cara untuk mencapai tujuan, strategi sebagai sebuah pola adalah sebuah tindakan konsisten dan teratur yang dijalankan organisasi dalam waktu yang lama, strategi sebagai sebuah posisi merupakan cara organisasi dalam menempatkan sesuatu pada tempat yang tepat (Tabroni 2014).

Menurut Budiardjo komunikasi politik adalah salah satu fungsi partai politik, yakni menyalurkan aneka ragam pendapat dan aspirasi masyarakat serta mengaturnya sedemikian rupa "penggabungan kepentingan" dan "perumusan kepentingan" untuk diperjuangkan menjadi kebijakan politik (Tabroni 2014). Menurut Jack Plano dkk, komunikasi politik merupakan penyebaran aksi, makna, atau pesan yang bersangkutan dengan fungsi suatu sistem politik, melibatkan unsur-unsur komunikasi, seperti komunikator, pesan dan lainnya (Tabroni 2014). Komunikasi politik pada praktiknya akan melibatkan aspek-aspek bagaimana seseorang belajar politik, bagaimana seseorang menemukan sikap serta nilai-nilai berkenaan dengan kelembagaan politik, dan bagaimana seseorang pada akhirnya berperilaku politik tertentu. Komunikasi politik merupakan proses belajar, proses menerima dan proses improvisasi kebiasaankebiasaan dan aturan-aturan, struktur-struktur, serta faktor-faktor lingkungan yang membentuk kehidupan politik.

Menurut Mc Nair tujuan seseorang melakukan komunikasi politik adalah sebagai bagian dari proses pembelajaran politik, yang terjadi akibat adanya proses pertukaran informasi. Aktor politik dapat belajar memahami konsituen, masyarakat dan pemberitaan media, demikian juga sebaliknya (Tabroni 2014). Komunikasi politik juga bertujuan untuk menumbuhkan partisipasi masyarakat dalam politik. Melalui pembelajaran politik, orang mengembangkan kepercayaan, nilai dan harapan yang pada gilirannya mendorong untuk berpartisipasi dalam politik, wujudnya bisa berbentuk memberikan suara pada saat pencoblosan. Riset dibidang komunikasi politik selalu digunakan oleh partai politik dalam pemilihan umum. Strategi komunikasi politik adalah keseluruhan keputusan kondisional tentang tindakan yang akan dijalankan saat ini, guna mencapai tujuan politik masa depan. Merawat ketokohan, memantapkan 
kelembagaan, menciptakan kebersamaan dan membangun konsensus merupakan keputusan yang tepat bagi komunikator politik (Arifin 2011).

Menurut Peter H. Odegard dan David Easton ilmu politik sebagai ratunya ilmu-ilmu sosial (the queen of social science) yang berkedudukan pada peringkat paling atas diantara ilmu-ilmu sosial, atau ilmu yang utama khususnya diantara kelompok ilmu sosial (kemasyarakatan dan kemanusiaan) (Rudy 2007). Menurut Aristoteles, secara alamiah manusia adalah makhluk yang berpolitik "zoon politicon", bahwa politik merupakan hakikat keberadaan manusia dalam kehidupan masyarakat. Jika dua orang atau lebih berinteraksi satu sama lain (dalam menjalani kehidupan di dunia), maka mereka tidak lepas dari keterlibatan dalam hubungan yang bersifat politik. Bagi negara yang menganut sistem pemerintahan demokrasi, partai politik menjadi sarana demokrasi yang bisa berperan sebagai penghubung antara rakyat dan pemerintah (Rudy 2007).

Menurut Budiardjo dalam Cangara (2011), partai politik adalah suatu kelompok yang terorganisasi yang anggota-anggotanya mempunyai orientasi, nilai-nilai, dan citacita yang sama. Menurut UU No. 2 tahun 2011 pasal 1 tentang partai politik dinyatakan bahwa "partai politik dalah organisasi politik yang dibentuk oleh sekelompok warga negara Republik Indonesia secara sukarela atas dasar persamaan kehendak dan citacita memperjuangkan kepentingan anggota, masyarakat, bangsa dan negara melalui pemilihan umum". Adapun Soltau mendefinisikan partai politik sebagai kelompok warga negara yang sedikit banyak terorganisasikan, yang bertindak sebagai satu kesatuan politik dan dengan memanfaatkan kekuasaannya untuk memilih, bertujuan untuk menguasai pemerintahandan menjalankan kebijakan umum yang mereka buat (Djuyandi 2017). Menurut Giovanni Sartori partai politik adalah suatu kelompok politik yang mengikuti pemilu dan melalui pemilu itu, mampu menempatkan calon-calonnya untuk menduduki jabatan publik (Djuyandi 2017).

\section{METODE PENELITIAN}

Pendekatan yang digunakan dalam penelitian ini adalah pendekatan penelitian kualitatif, yaitu penelitian yang bermaksud untuk memahami fenomena tentang apa 
yang dialami oleh subjek penelitian (perilaku, persepsi, motivasi, tindakan) secara holistik dan dengan cara deskripsi dalam bentuk kata-kata dan bahasa. Jenis penelitian ini adalah penelitian deskriptif, yang berarti berupaya menggambarkan secara umum tentang masalah yang diteliti. Adapun teknik pengumpulan data dalam penelitian ini adalah teknik wawancara dan dokumentasi. Teknik analisa data yang penulis gunakan dalam penelitian ini adalah bersifat deskriptif kualitatif, yaitu mereduksi data, memilih hal-hal pokok, kemudian dilakukan penyajian data dalam bentuk uraian singkat, bagan, hubungan antar kategori dan kemudian diambil kesimpulan dan saran.

\section{PEMBAHASAN}

Berdasarkan fakta-fakta yang penulis lihat di lapangan pada pemilu tahun 2019 PKS meraih 8 kursi untuk DPRD Kota Pekanbaru. Salah satu faktor meningkatnya perolehan suara adalah strategi komunikasi politik yang baik. Dalam partai politik, strategi komunikasi politik adalah salah satu teknik untuk mendapatkan kemenangan dan tercapainya suatu tujuan. Untuk menjelaskan pembahasan dalam penelitian ini penulis menggunakan teori strategi komunikasi politik. Riset di bidang komunikasi politik selalu digunakan oleh partai politik dalam pemilihan umum. Strategi komunikasi politik adalah keseluruhan keputusan kondisional tentang tindakan yang akan dijalankan saat ini, guna mencapai tujuan politik masa depan. Merawat ketokohan, memantapkan kelembagaan, menciptakan kebersamaan dan membangun konsensus merupakan keputusan yang tepat bagi komunikator politik (Arifin, 2011:235).

\section{Ketokohan dan Kelembagaan}

\section{a. Merawat Ketokohan}

Ketokohan adalah orang yang memiliki kredibilitas (al amin), daya tarik, dan kekuasaan. Dengan kata lain, ketokohan sama dengan ethos, yaitu gabungan antara kredibilitas, atraksi dan kekuasaan. Orang yang memiliki ketokohan dapat disebut juga pahlawan politik. Dalam komunikasi politik pada hakikatnya masyarakat akan memperhatikan siapa tokoh politik ketimbang apa pesan politik yang akan disampaikan. Hal ini menunjukkan bahwa ketokohan adalah hal sangat utama dalam komunikasi politik. 
Adapun upaya PKS untuk merawat ketokohan yaitu caleg yang ingin maju diseleksi yang dinilai orang-orang yang bersangkutan punya ketokohan di masyarakat misalnya ketua RW, LPM, imam masjid, dan tokoh masyarakat lainnya dimana PKS melakukan pembinaan terhadap mereka agar memenuhi menjadi syarat dalam mekanisme kaderisasi partai. Upaya lain yang dilakukan adalah dengan membawa Ayat Cahyadi (wakil wali kota) turun ke dapil sehingga bisa membangun kedekatan masyarakat dan PKS. Caleg dan kader PKS diminta oleh partai banyak-banyak berinteraksi dengan masyarakat, melakukan kegiatan-kegiatan sosial, mengisi pengajian, pembuatan sumur bor, gotong royong. Ketokohan caleg-caleg PKS kinerjanya mendekati dan peduli kepada masyarakat, sosok yang religius.

\section{b. Memantapkan Kelembagaan}

Memantapkan kelembagaan adalah upaya memperbesarkan dan mempercantik lembaga politiknya. Hal itu sangat penting sebagai faktor yang mendasar dalam komunikasi politik, terutama yang berkaitan dengan kampanye dan dukungan elektoral dari warga. Lembaga juga memiliki karakteristik seperti manusia yang meliputi eksistensi, kepribadian dan aktivitas. Ketokohan seorang politikus akan meningkat jika ia berkiprah dalam lembaga partai politik yang ternama. Memantapkan kelembagaan dan merawat ketokohan adalah keterkaitan yang tidak bisa dipisahkan karena saling berhubungan erat. Lembaga dan tokoh politik adalah dua hal yang berjalan beriringan karena saling membutuhkan. Begitu juga hal yang dilakukan PKS untuk memantapkan kelembagaan dengan meningkatkan kemampuan-kemampuan ketua DPC, DPA bahkan para kader sehingga PKS dapat dikenal oleh masyarakat luas serta peduli kepada masyarakat, banyak berkontribusi, mengisi ceramah di mesjid. PKS adalah partai kader sehingga salah satu cara yang dilakukan untuk memantapkan kelembagaannya adalah dengan merawat ketokohan-ketokohan para kader tersebut.

\section{Menciptakan Kebersamaan}

\section{a. Memahami Khalayak}


Para politikus harus mengenali, memahami, mengetahui kebutuhan dan motivasi khalayak. Para pemilih memberikan suaranya kepada suatu partai atau kandidat berdasarkan ideologi atau kayakinan politiknya. Beberapa masyarakat memilih partai dengan alasan partai tersebut membela agama dan memihak kepada kemajemukan. Beberapa masyarakat lainnya memilih partai politik dengan alasan partai tersebut kebijakannya memihak kepada rakyat kecil. Dalam memahami khalayak cara yang dilakukan PKS adalah melakukan silaturahim, setiap kader mengunjungi 40 rumah sebelum masa kampanye atau dilakukan jauh-jauh hari, bermasyarakat di mesjid, musholla, gotong royong, menyampaikan pesan-pesan Islam sesuai dengan ideologi partai. Hal ini dilakukan PKS bukan hanya karena pemilu saja akan tetapi sudah menjadi kebiasaan.

\section{b. Menyusun Pesan Persuasif}

Bertolak dari paradigma khalayak aktif di negara demokrasi, sesungguhnya khalayaklah yang menentukan pesan politik yang harus disampaikan oleh para politikus dalam kampanye politiknya, baik dalam menggunakan retorika politik (pidato) maupun melalui media politik, pesan politik disusun setelah mengetahui kondisi masyarakat. Pesan politik adalah pesan yang dapat menimbulkan perhatian, pesan yang mudah diperoleh dan karena itu perbedaannya harus menyolok dengan pesan-pesan yang lain. Dalam menyusun pesan persuasif upaya yang dilakukan oleh PKS adalah menyampaikan pesan-pesan umum dengan sajian yang berbeda berdakwah misalnya, berdasarkan fakta-fakta yang penulis lihat adapun program khusus yang PKS tawarkan kepada masyarakat adalah secara nasional kalau PKS menang yaitu akan diberlakukannya SIM seumur hidup, pajak motor dihapus, perlindungan ulama, bebas pajak untuk penghasilan dibawah 8 juta perbulan.

\section{c. Menetapkan Metode}

Metode yang diterapkan dalam strategi komunikasi politik memang cukup banyak. Arifin (2011) menawarkan metode komunikasi yang dapat dipilih sesuai dengan kondisi dan 
situasi khalayak, yaitu: redudancy, canalizing, informative, persuasif, educative, coersive. Adapun metode yang digunakan oleh PKS adalah metode educative sebagai salah satu usaha untuk mempengaruhi khalayak dari suatu pernyataan yang dilontarkan, yang dapat diwujudkan dalam bentuk pesan yang berisi pendapat, fakta dan pengalaman. Sehingga dari fakta dan pengalaman-pengalaman tersebut bisa merangkul orang-orang terdekatnya untuk memilih PKS. Metode yang digunakan oleh PKS adalah dengan cara yang halal bukan menghalalkan segala cara.

\section{d. Memilah dan Memilih Media}

Sesuai dengan eksistensi media sebagai perpanjangan indera manusia, media hanya diperlukan untuk komunikasi jarak jauh, sedangkan untuk komunikasi jarak dekat atau tatap muka tentu media tidak diperlukan. Untuk berkomunikasi jarak jauh dengan orang banyak (massa), diperlukan media massa atau media internet. Dalam komunikasi politik, seluruh media dapat dipergunakan karena tujuannya adalah untuk membentuk dan membina pendapat umum, serta mempengaruhi pemberi suara dalam pemilu. Berdasarkan fakta-fakta yang penulis lihat di lapangan media yang digunakan oleh PKS selama berkampanye dan sosialisasi untuk meningkatkan perolehan suara pada pemilu tahun 2019 yaitu semua media digunakan dari baliho, media sosial. Hal ini dilakukan agar masyarakat dapat mengenal partai politik dan para kader bahkan caleg PKS.

\section{Membangun Konsensus}

\section{a. Seni Berkompromi}

Dalam membangun konsensus seorang politikus atau aktivis harus memiliki kemampuan berkompromi, yaitu merupakan suatu seni tersendiri. Maka dari itu, bagaimana seni berkompromi PKS apabila terjadinya konflik, perbedaan pendapat, pandangan. Berdasarkan fakta-fakta yang penulis lihat di lapangan, adapun hal-hal yang dilakukan PKS ialah dengan cara musyawarah atau disebut syuro, dengan adanya syuro sehingga dapat memecahkan konflik dan menemukan solusi.

\section{b. Bersedia Membuka Diri}


Para politikus yang akan melakukan lobi untuk mencari solusi dengan membangun konsensus harus memulai dengan kesediaan membuka diri. Berdasarkan beberapa fakta yang penulis lihat di lapangan PKS adalah partai yang terbuka kepada siapapun bukan hanya Islam bahkan non-muslim pun, bekerja sama dengan pihak lain, menerima masukan, kritikan, sehingga bisa menjadi acuan untuk PKS menjadi suatu partai yang lebih baik lagi.

Berbicara mengenai politik uang merupakan salah satu topik yang sangat banyak dibicarakan pada saat pemilu. Para caleg berlomba-lomba untuk merebut suara masyarakat bahkan sampai menghalalkan segala cara. Politik uang adalah pertukaran uang dengan maksud untuk menentukan posisi seseorang. Berdasarkan fakta yang penulis lihat di lapangan PKS sangat menolak dan melawan politik uang, PKS mengarahkan kepada para kader untuk tidak melakukan hal-hal yang membodohi masyarakat. Banyak cara lain yang dilakukan untuk memperoleh suara masyarakat buakn dengan cara yang haram. PKS mengajak para kader untuk meninggalkan budaya-budaya yang merusak demokrasi, berpolitiklah dengan jujur.

\section{KESIMPULAN}

Merujuk kepada uraian yang telah penulis sampaikan pada pembahasan sebelumnya, maka dapat ditarik kesimpulan berupa, semua teori tersebut sangat berperan penting dalam meningkatkan perolehan suara PKS pada pemilu tahun 2019 di Kota Pekanbaru, akan tetapi yang paling dominan adalah pesan politik yang disampaikan oleh PKS berbeda dengan pesan-pesan politik lainnya sehingga menyebabkan perolehan suara PKS meningkat dari tahun-tahun sebelumnya. Pada tahun 2014 PKS meraih 3 kursi akan tetapi pada pemilu tahun 2019 PKS meraih 8 kursi.

\section{REFERENSI}

Arifin, Anwar. 2011. Komunikasi Politik: Filsafat, Paradigma, Teori, Tujuan, Strategi, dan Komunikasi Politik Indonesia. Yogyakarta: Graha IImu.

Cangara, Hafied. 2011. Komunikasi Politik: Konsep, Teori dan Strategi. Jakarta: PT Raja Grafindo Persada. 
Ismail (2013) "Strategi politik Partai Keadilan Sejahtera (PKS) dalam memenangkan pemilu Legislatif di Kabupaten Kampar tahun 2019". Riau. Universitas Abdurrab.

Mufti, Muslim. 2011. Teori-Teori Demokrasi. Bandung: CV Pustaka Setia.

Rosit, M (2012) "Strategi komunikasi politik dalam Pilkada (studi kasus pemenangan pasangan kandidat Ratu Atut dan Rano Karno pada Pilkada Banten 2011". Jakarta. Universitas Indonesia.

Rudy, Teuku May. 2007. Pengantar Ilmu Politik: Wawasan Pemikiran dan Kegunaannya. Bandung: PT Refika Aditama.

Santoso, Joko. (2010) "Strategi Politik Partai Keadilan Sejahtera pada Pemilu 2009 di D.I Yogyakarta dalam Perfektif Fiqih Siyasah". Yogyakarta. Universitas Islam Negeri Sunan Kalijaga.

Subakti, Ramlan. 2010. Memahami Ilmu Politik. Jakarta: PT Grasindo.

Suryani, Ade. (2017) "Strategi komunikasi politik Partai Golkar dalam memenangkan pemilihan umum Legislatif tahun 2014 di Kota Pekanbaru". Riau. Universitas Abdurrab.

Tabroni, Roni. 2014. Komunikasi Politik Pada Era Multimedia. Bandung: Simbiosa Rekatama Media.

Ubaedillah, A. 2015. Pendidikan Kewarganegaraan (civic education) Pancasila, Demokrasi, dan Pencegahan Korupsi. Jakarta: Pranadamedia Group.

UU No. 2 Tahun 2011 tentang Partai Politik.

UU No. 7 Tahun 2017 tentang Pemilu.

\section{Sumber Wawancara}

Asep Haryana. Ketua DPC PKS Tampan. Wawancara Tahun 2019

Efrizal, Warga Marpoyan Damai RW 08 RT 04, Wawancara Tahun 2019

Hamdani. Ketua Bidang Pemberdayaan Jaringan Usaha dan Ekonomi Kader. Wawancara Tahun 2019

M. Zainudin. Caleg PKS Dapil IV Tampan. Wawancara Tahun 2019

Sarianto. Warga/Kader PKS. Wawancara Tahun 2019.

Sofyan Siroj. Ketua Umum DPD PKS Pekanbaru. Wawancara Tahun 2019. 
Sony Martin. Sekretaris Umum DPD PKS Pekanbaru. Wawancara Tahun 2019.

Yusriadi. Ketua Bapilu DPW PKS Riau. Wawancara Tahun 2019. 